\title{
Faktor Penyumbang kepada Tekanan Perumahan di Kawasan Perumahan Kos Rendah dan Sederhana Rendah di Pulau Pinang
}

\section{Factors Contributing to Housing Stress in Low and Low-Medium Cost Housing in Pulau Pinang}

\author{
NOORIAH YUSOF \\ School of Humanities, Universiti Sains Malaysia, 11800 USM Pulau Pinang, Malaysia \\ nooriah@usm.my
}

Published online: 15 May 2019

To cite this article: Yusof, N. 2019. Faktor penyumbang kepada tekanan perumahan di kawasan perumahan kos rendah dan sederhana rendah di Pulau Pinang. KEMANUSIAAN the Asian Journal of Humanities 26(1): 143-171, https://doi.org/10.21315/kajh2019.26.1.6

To link to this article: https://doi.org/10.21315/kajh2019.26.1.6

\begin{abstract}
Abstrak. Rumah sebagai tempat kediaman memainkan peranan penting dalam pembangunan lestari ke arah meningkatkan kesejahteraan hidup penduduk. Isu perumahan khususnya perumahan kos rendah dan sederhana rendah dalam bandar daripada segi penawaran-permintaan, kenaikan harga rumah dan kualiti perumahan serta tekanan perumahan telah menunjukkan bahawa perumahan merupakan satu isu kritikal yang perlu diberikan perhatian. Tekanan perumahan atau housing stress lazimnya merujuk kepada kekangan kewangan sebagai penyebab kepada ketidakmampuan pemilikan rumah dan mengurus kos perbelanjaan perumahan. Namun, didapati bebanan kewangan sematamata bukan merupakan faktor yang menyumbang kepada tekanan perumahan, sebaliknya terdapat faktor-faktor lain yang berkaitan dengan perumahan yang juga boleh membawa kepada tekanan perumahan. Tekanan perumahan terdiri daripada dua jenis, iaitu tekanan fizikal dan tekanan emosi yang boleh memberi kesan negatif terhadap kehidupan penghuni. Makalah ini membincangkan persepsi responden kajian terhadap faktor-faktor yang menyumbang kepada tekanan perumahan. Perbincangan dibuat berdasarkan hasil kajian empirikal yang telah dijalankan melalui edaran borang soal selidik kepada 400 penghuni perumahan kos rendah dan sederhana rendah dalam bandar di Pulau Pinang. Hasil dapatan kajian menunjukkan bahawa faktor kualiti perumahan dan kualiti persekitaran kawasan perumahan sebenarnya lebih banyak menyumbang kepada tekanan perumahan berbanding faktor ekonomi walaupun majoriti responden memperuntukkan lebih daripada 30 peratus pendapatan untuk kos perumahan.
\end{abstract}

Kata kunci dan frasa: tekanan perumahan, perumahan kos rendah dan sederhana rendah, kesejahteraan hidup, kawasan bandar, Pulau Pinang 
Abstract. A house as a place of residence plays an important role towards sustainable development and in improving the well-being of the population. The issue of housing, especially the supply and demand of low and low-medium cost housing in cities, rising house prices, quality of housing as well as housing stress has shown that housing is a critical issue that must be addressed. Housing stress usually refers to financial constraints, the reason for the inability to manage the cost of home ownership and housing expenses. Yet financial burden is not the only factor that can contribute to housing stress. There are two types of housing stress, namely physical and emotional factors that may impact negatively on the lives of residents. This paper discusses perceptions of factors that may contribute to housing stress based on a survey of 400 residents of low and low-medium cost housing areas in Pulau Pinang. The results of the study show that although majority of the respondents allocate more than 30 percent of their income for housing, the quality of housing and the environmental quality of housing areas contribute more to their housing stress than economic factors.

Keywords and phrases: housing stress, low and low-medium cost housing, well-being, urban areas, Pulau Pinang

\section{Pendahuluan}

Rumah yang merupakan keperluan asas kepada kehidupan manusia tidak sekadar merupakan satu binaan fizikal semata-mata tetapi juga berperanan dalam meningkatkan kesejahteraan hidup. Bagi penduduk berpendapatan rendah dan sederhana, khususnya di kawasan bandar, terdapat banyak isu berkaitan perumahan yang membelenggu golongan ini. Isu perumahan seperti penawaranpermintaan, kenaikan harga rumah dan kualiti rumah telah banyak diberi perhatian dan diselidiki. Namun, tidak banyak kajian yang melihat daripada segi pengaruh rumah terhadap kesejahteraan hidup, khususnya dalam meneliti kesan tekanan perumahan yang dialami oleh penduduk. Tekanan perumahan atau housing stress lazimnya merujuk kepada kekangan kewangan yang dialami oleh penduduk dalam memenuhi hasrat untuk memiliki rumah dan mengurus kos perbelanjaan rumah. Namun, didapati bahawa bebanan kewangan semata-mata bukan merupakan faktor yang menyumbang kepada tekanan perumahan. Faktor-faktor perumahan yang lain seperti kualiti rumah dan kualiti persekitaran kawasan perumahan juga boleh memberi tekanan kepada penghuni. Terdapat dua jenis tekanan perumahan, iaitu tekanan fizikal dan tekanan emosi, yang mana ia boleh memberi kesan negatif kepada penghuni. Makalah ini akan membincangkan faktor-faktor yang menyumbang kepada tekanan perumahan dalam kalangan penduduk di kawasan perumahan kos rendah dan sederhana rendah dalam bandar di Pulau Pinang. 


\section{Perumahan dan Kesejahteraan Hidup}

Rumah atau tempat tinggal telah dikenal pasti sebagai keperluan asas kepada manusia. Rumah merupakan keperluan asas yang utama untuk kehidupan fizikal dan sosial. Menurut Fang (2005), konsep keperluan perumahan menunjukkan bahawa kepuasan pemilikan kediaman akan tercapai apabila keperluan perumahan individu dapat dipenuhi. Rumah menjadi tempat asas untuk keluarga berlindung dan sebagai ruang peribadi individu yang penting dalam mencapai kesejahteraan kesihatan mental dan fizikal. Ketiadaan dan kesukaran memiliki rumah yang memuaskan boleh memberi kesan ekonomi dan sosial terhadap individu, termasuk kesan keterpinggiran sosial, gelandangan, kesihatan mental, ketidakjaminan pendapatan, perpecahan keluarga dan tekanan perumahan (Lawson dan Miligan 2008). Grimes, Kerr dan Aitken (2003) menyatakan bahawa rumah merupakan komponen kekayaan yang paling utama kepada kebanyakan manusia. Hal ini adalah kerana trend perumahan boleh mempengaruhi kebajikan penduduk sama ada secara langsung atau tidak langsung. Malah, sektor perumahan juga merupakan sektor penting dalam aktiviti ekonomi yang bukan sahaja menyediakan kemudahan penempatan kepada penduduk tetapi juga dapat menunjukkan status kekayaan dan situasi ekonomi semasa mereka.

Perumahan bukan sahaja berperanan sebagai komponen guna tanah utama dalam bandar, malah turut memainkan peranan penting sebagai sektor utama yang menjana dan memacu perkembangan industri hartanah dan pertumbuhan ekonomi pada peringkat tempatan dan nasional. Sektor ini telah mengalami perubahan pemikiran dan aspirasi dari semasa ke semasa, daripada melihat perumahan sebagai "tempat kediaman" kepada memastikan perumahan yang disediakan adalah mencukupi dan mampu dimiliki oleh pelbagai golongan masyarakat sehinggalah kepada keperluan untuk menikmati persekitaran perumahan yang kondusif, selesa, berkualiti, selamat dan harmoni (Jabatan Perumahan Negara 2016). Hal ini menunjukkan bahawa perumahan memainkan peranan penting dalam mempengaruhi kesejahteraan hidup penduduk. Namun demikian, saling hubung antara perumahan dengan kesejahteraan hidup masih banyak yang belum difahami sepenuhnya. Polisi awam juga tidak memberi perhatian yang tinggi kepada impak perumahan terhadap kesejahteraan hidup dan psikologi penghuni (Baqutayan 2016). Kajian tentang perumahan, tekanan dan kesihatan menunjukkan pola saling kaitan yang jelas antara pencetus tekanan perumahan dengan tekanan psikologi (Cantarero dan Potter 2012).

Sekiranya sebelum ini tekanan perumahan banyak dikaitkan dengan ketidakmampuan memiliki rumah dan ketidakcukupan perumahan, namun kini didapati banyak faktor perumahan yang lain juga boleh membawa kepada tekanan 
perumahan. Hal ini menunjukkan bahawa faktor-faktor dalam persekitaran ruang kehidupan (ekonomi, sosial dan alam sekitar) boleh menjadi sumber utama kepada tekanan yang dihadapi. Sebagai contoh, banyak kajian mendapati bahawa tekanan perumahan berlaku disebabkan oleh faktor yang berkaitan dengan kesesakan yang telah memberi kesan signifikan terhadap psikologi penduduk (Evans et al. 2000; Mueller dan Tighe 2007). Kehidupan di bandar, khususnya dengan jumlah penduduk yang ramai dan padat, telah menimbulkan banyak faktor yang boleh mencetuskan tekanan kepada penduduk seperti kesesakan, bunyi bising daripada trafik yang tinggi dan kebimbangan terhadap keselamatan (Berg, Hartig dan Staats 2007). Kesan psikologi telah mula diakui memainkan peranan penting dalam mempengaruhi kesejahteraan hidup penduduk khususnya dalam mengimbangi antara kepadatan kawasan bandar (compact city) dengan keinginan manusia terhadap persekitaran hidup yang selesa, hijau dan tenang.

Kepesatan proses perbandaran dan pertumbuhan penduduk telah menyebabkan komuniti bandar bersaing untuk mendapatkan kualiti hidup yang baik. Peningkatan kos sara hidup di bandar turut memberi kesan terhadap kemampuan mengurus kos perumahan dalam kalangan komuniti tertentu dalam bandar. Golongan berpendapatan rendah dan sederhana selalunya menghadapi kekangan yang besar dalam menangani cabaran ini. Peningkatan harga rumah menyulitkan lagi keputusan yang perlu dibuat antara menanggung kos rumah yang tinggi dengan terpaksa berkompromi dengan kualiti dan lokasi atau persekitaran kawasan perumahan (Baqutayan 2016). Mereka terpaksa membuat tukar ganti atau trade off supaya mampu untuk membiayai kos rumah yang tinggi dengan terpaksa menerima kualiti rumah yang kurang memuaskan walaupun tidak mencapai tahap kepuasan yang diinginkan. Hal ini menyebabkan golongan ini berada dalam kelompok yang mudah terjejas yang boleh memberi kesan terhadap kesejahteraan hidup.

Kualiti hidup amat penting dalam sesebuah negara kerana ia merupakan pengukur yang efektif dalam menilai tahap kemajuan dan kesejahteraan hidup sesebuah komuniti. Perumahan merupakan elemen penting kepada penempatan penduduk dalam memenuhi keperluan asas dan kualiti hidup yang menjadi aset yang sangat berharga untuk keperluan ekonomi, sosial dan kepentingan peribadi (Kajimo dan Evans 2006). Kesejahteraan merujuk kepada taraf dan kualiti hidup yang memenuhi keperluan sosioekonomi, fizikal dan psikologi individu yang menyumbang kepada peningkatan produktiviti dan mobiliti sosial serta dapat mengukuhkan kesepaduan sosial dan nasional (Malaysia 2015). Menurut Atchley (2004), kesejahteraan merujuk kepada perasaan bebas daripada tekanan, berasa gembira dalam jangka masa panjang dan berperasaan positif dengan kehidupan. Menurut Tosics (2004) pula, perumahan merupakan salah satu dasar awam yang paling penting kerana ia memberi kesan kepada pembangunan bandar dan berpotensi menyumbang kepada 
kelestarian hidup komuniti dan bandar. Jika semua komuniti mempunyai peluang akses kepada perumahan yang baik, maka perumahan tersebut dapat menggalakkan perpaduan sosial, kesejahteraan dan kepercayaan diri (Edwards dan Turrent 2000). Menurut Maliene dan Malys (2009), perumahan lestari perlu mempunyai ciri-ciri yang dapat memenuhi keperluan sosial penduduk dan persekitaran yang mampu menjadikan rumah yang didiami boleh menyumbang kepada kesejahteraan hidup penghuninya. Rajah 1 menunjukkan beberapa komponen utama dalam perumahan lestari yang mengambil kira aspek ekonomi, sosial dan persekitaran serta kuantiti dan kualiti perumahan bagi menjamin keselesaan hidup penduduk.

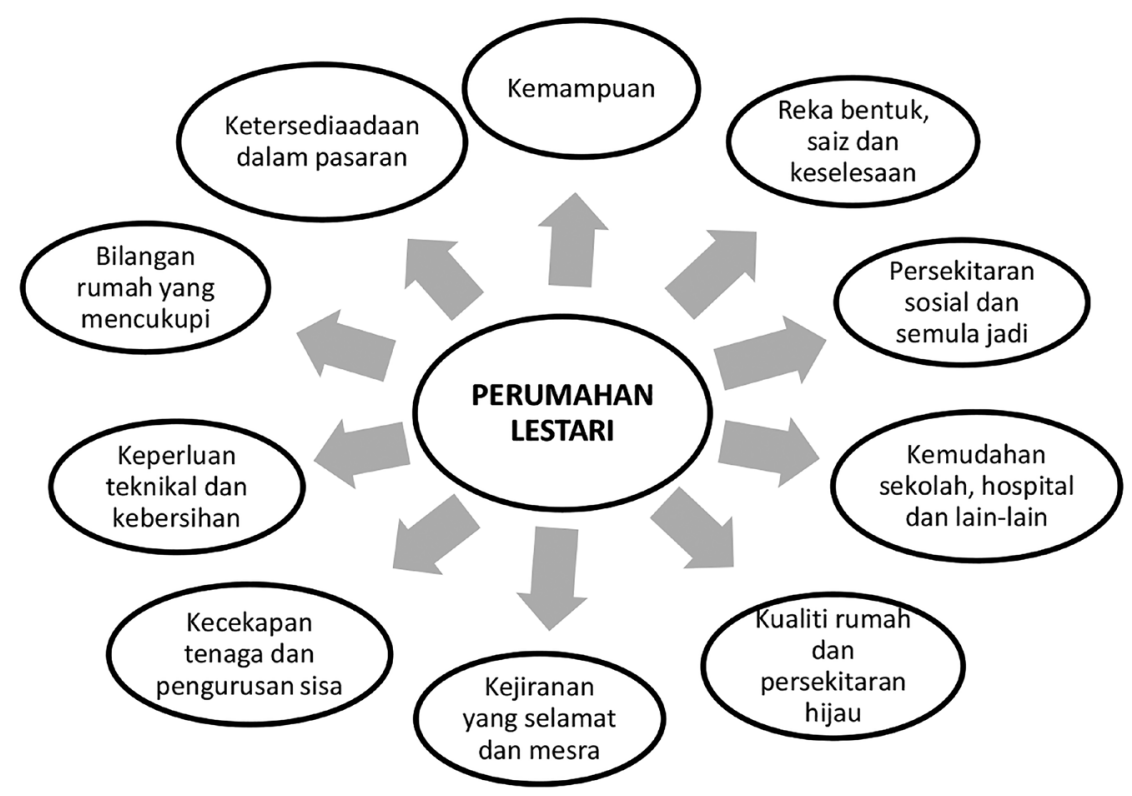

Rajah 1. Ciri-ciri perumahan lestari

Sumber: Maliene dan Malys (2009)

\section{Isu Perumahan Kos Rendah dan Sederhana Rendah dalam Bandar}

Perumahan kos rendah pada dasarnya dibina untuk memenuhi keperluan penduduk yang berpendapatan rendah atau dikategorikan sebagai miskin. Perumahan ini seharusnya mampu dimiliki oleh golongan ini dengan tawaran harga rumah yang rendah. Di kawasan bandar yang pesat membangun dan ditambah pula dengan peningkatan nilai tanah yang tinggi telah membawa cabaran yang besar kepada penyedia perumahan (sama ada kerajaan atau pihak swasta) untuk membangun dan membiayai projek perumahan kos rendah dalam bandar. Hal ini menyebabkan penawaran perumahan kos rendah dalam bandar adalah rendah berbanding perumahan kos tinggi. Permintaan terhadap perumahan turut meningkat sejajar 
dengan pertumbuhan penduduk yang pesat di kawasan bandar. Ruang tanah sedia ada untuk pembinaan rumah telah menjadi semakin terhad akibat persaingan sengit guna tanah untuk keperluan lain dalam bandar. Hal ini juga telah menyebabkan harga tanah semakin meningkat dan mengakibatkan harga semua jenis hartanah, termasuk rumah, turut naik. Akhirnya, golongan ini akan tinggal di kawasan setinggan kerana tidak mampu membeli atau menyewa rumah yang sesuai untuk didiami (Nurizan dan Ahmad 2001), apatah lagi dengan penawaran rumah kos rendah yang terhad dalam pasaran.

Jadual 1 menunjukkan peratusan perumahan kos rendah dalam bandar di Malaysia sehingga September 2018. Walaupun keperluan untuk perumahan ini adalah tinggi, namun keupayaan untuk menyediakan perumahan kos rendah dalam bandar agak terhad. Unit rumah yang siap dibina hanyalah 3.9 peratus sahaja daripada jumlah keseluruhan rumah yang dirancang. Sementara itu, daripada segi penawaran dan perancangan perumahan kos rendah pada masa hadapan, didapati peratusan penawaran dan perancangan perumahan kos rendah adalah tidak melebihi 16 peratus. Jadual 2 menunjukkan data bilangan unit rumah yang telah diluluskan untuk pembinaan bagi tahun 2016. Didapati bahawa rumah kos rendah dan sederhana rendah mencatatkan peratusan yang sangat rendah, iaitu hanya 1.1 peratus dan 0.4 peratus masing-masing berbanding rumah kos tinggi yang mencatatkan lebih daripada 96 peratus. Selain itu, dalam Rancangan Malaysia ke-10 (2011-2015), kualiti pembinaan yang rendah bagi sektor perumahan kos rendah telah dikenal pasti sebagai satu isu utama yang perlu diberikan perhatian.

Jadual 1. Status perumahan kos rendah mengikut negeri di Malaysia (sehingga September 2018)

\begin{tabular}{|c|c|c|c|c|c|c|}
\hline \multirow{3}{*}{ Negeri } & \multicolumn{6}{|c|}{ Perumahan kos rendah (September 2018) } \\
\hline & \multicolumn{3}{|c|}{ Stok sedia ada (rumah sedia ada) } & \multicolumn{3}{|c|}{ Unit rumah yang siap dibina } \\
\hline & Jumlah* & Bil. & Peratus & Jumlah* & Bil. & Peratus \\
\hline Johor & 808,283 & 202,189 & 25.0 & 8,728 & 88 & 1.0 \\
\hline Kedah & 328,062 & 107,777 & 32.9 & 2,902 & 239 & 8.2 \\
\hline Kelantan & 80,286 & 27,789 & 34.6 & 1,545 & 64 & 4.1 \\
\hline Melaka & 190,896 & 36,941 & 19.4 & 2,357 & 250 & 10.6 \\
\hline Negeri Sembilan & 267,549 & 35,927 & 13.4 & 2,932 & 0 & 0 \\
\hline Pahang & 271,627 & 65,161 & 24.0 & 3,874 & 41 & 1.1 \\
\hline Perak & 476,033 & 93,812 & 19.7 & 6,696 & 32 & 0.5 \\
\hline Perlis & 25,795 & 10,476 & 40.6 & 331 & 0 & 0 \\
\hline Pulau Pinang & 506,596 & 80,599 & 15.9 & 5,299 & 686 & 12.9 \\
\hline
\end{tabular}


Jadual 1 (sambungan)

\begin{tabular}{|c|c|c|c|c|c|c|}
\hline \multirow{3}{*}{ Negeri } & \multicolumn{6}{|c|}{ Perumahan kos rendah (September 2018) } \\
\hline & \multicolumn{3}{|c|}{ Stok sedia ada (rumah sedia ada) } & \multicolumn{3}{|c|}{ Unit rumah yang siap dibina } \\
\hline & Jumlah* & Bil. & Peratus & Jumlah* & Bil. & Peratus \\
\hline Sabah & 212,008 & 48,80 & 23.0 & 2,214 & 420 & 19.0 \\
\hline Sarawak & 253,197 & 34,16 & 13.5 & 5,825 & 545 & 9.4 \\
\hline Selangor & $1,527,493$ & 277,90 & 18.2 & 8,762 & 173 & 2.0 \\
\hline Terengganu & 100,073 & 26,00 & 26.0 & 2,237 & 151 & 6.8 \\
\hline W.P. Kuala Lumpur & 477,299 & 106,20 & 22.3 & 0 & 0 & 0 \\
\hline W.P. Labuan & 12,441 & 1,95 & 15.7 & 0 & 0 & 0 \\
\hline W.P. Putrajaya & 0 & & 0 & 0 & 0 & 0 \\
\hline Jumlah & $5,550,250$ & $1,155,7$ & 20.8 & 68,739 & 2,710 & 3.9 \\
\hline \multirow{3}{*}{ Negeri } & \multicolumn{6}{|c|}{ Perumahan kos rendah } \\
\hline & \multicolumn{3}{|c|}{$\begin{array}{c}\text { Penawaran perumahan } \\
\text { akan datang }\end{array}$} & \multicolumn{3}{|c|}{$\begin{array}{c}\text { Penawaran perumahan } \\
\text { yang dirancang }\end{array}$} \\
\hline & Jumlah* & Bil. & Peratus & Jumlah* & Bil. & Peratus \\
\hline Johor & 68,588 & 3,242 & 4.7 & 88,247 & 7,396 & 8.4 \\
\hline Kedah & 16,436 & 1,514 & 9.2 & 14,552 & 2,086 & 14.3 \\
\hline Kelantan & 12,247 & 488 & 4.0 & 3,376 & 323 & 9.6 \\
\hline Melaka & 18,593 & 190 & 1.0 & 15,729 & 2,054 & 13.1 \\
\hline Negeri Sembilan & 21,887 & 178 & 0.8 & 34,991 & 2,185 & 6.2 \\
\hline Pahang & 22,763 & 1,117 & 4.9 & 35,118 & 621 & 1.8 \\
\hline Perak & 34,686 & 350 & 1.0 & 45,474 & 1,074 & 2.4 \\
\hline Perlis & 1,290 & 200 & 15.5 & 1,931 & 159 & 8.2 \\
\hline Pulau Pinang & 50,050 & 7,460 & 14.9 & 23,354 & 2,170 & 9.3 \\
\hline Sabah & 25,659 & 3,342 & 13.0 & 19,151 & 1,856 & 9.7 \\
\hline Sarawak & 20,857 & 614 & 2.9 & 6,738 & 714 & 10.6 \\
\hline Selangor & 115,694 & 1,870 & 1.6 & 78,064 & 5,960 & 7.6 \\
\hline Terengganu & 16,512 & 2,381 & 14.4 & 12,675 & 1,196 & 9.4 \\
\hline W.P. Kuala Lumpur & 0 & 0 & 0 & 0 & 0 & 0 \\
\hline W.P. Labuan & 0 & 0 & 0 & 0 & 0 & 0 \\
\hline W.P. Putrajaya & 0 & 0 & 0 & 0 & 0 & 0 \\
\hline Jumlah & 461,544 & 22,946 & 5.0 & 453,784 & 27,796 & 6.1 \\
\hline
\end{tabular}

Sumber: Di ubah suai daripada Jabatan Penilaian dan Perkhidmatan Harta (NAPIC), 2018, Laporan stok harta tanah, http://napic.jpph.gov.my/portal/web/guest/Publication-new (dicapai pada 20 Mac 2019).

Nota: *Jumlah merujuk kepada jumlah keseluruhan rumah yang terdiri daripada rumah sebuah berkembar, teres, rumah bandar, kelompok, kos rendah, rumah pangsa, pangsapuri khidmat dan pangsapuri, serta kondominium bagi setiap negeri. 
Jadual 2. Bilangan unit rumah yang diluluskan untuk pembinaan mengikut kategori perumahan

\begin{tabular}{lcc}
\hline Kategori perumahan & Bilangan unit & Peratus \\
\hline Kos rendah (<RM42,000) & 1,332 & 1.1 \\
Kos sederhana rendah (RM42,001-RM70,000) & 509 & 0.4 \\
Kos sederhana (RM70,001-RM100,000) & 1,958 & 1.7 \\
Kos tinggi (> RM100,000) & 112,850 & 96.7 \\
\hline Jumlah & 116,649 & 100.0 \\
\hline
\end{tabular}

Sumber: Jabatan Perumahan Negara (2016)

Menurut Nor Malina dan Azrina (2012), pada masa kini isu perumahan masih menjadi masalah utama dalam pembangunan bandar di negara ini, khususnya isu kekurangan penyediaan rumah bagi masyarakat berpendapatan rendah dan sederhana. Bagi golongan berpendapatan rendah, usaha untuk memiliki rumah yang merupakan satu keperluan asas melibatkan perbelanjaan yang besar. Masalah pemilikan rumah dalam kalangan komuniti berpendapatan rendah sentiasa menjadi satu cabaran yang besar kepada pemerintah dalam membangunkan dasar perumahan yang dapat memberi kelebihan kepada golongan ini. Hal ini menjadi semakin rumit, khususnya di kawasan bandar yang kekurangan tanah dan ditambah pula dengan nilai tanah yang tinggi telah menjadi kekangan utama kepada pembinaan perumahan kos rendah. Hal ini adalah kerana pemaju perumahan swasta lebih berminat untuk membangunkan projek perumahan kos tinggi bagi memperoleh keuntungan ke atas pelaburan yang dibuat, sementara pihak kerajaan mempunyai keupayaan yang terhad untuk membangunkan perumahan kos rendah dalam bandar. Rajah 2 menunjukkan jurang dalam penyediaan rumah mengikut kategori perumahan oleh pihak swasta di Malaysia bagi tahun 2014.

Dalam memenuhi keperluan perumahan, faktor-faktor seperti kemampuan pembeli, kos pembangunan dan harga jualan sentiasa mempengaruhi permintaan dan penawaran sektor perumahan. Bagi golongan berpendapatan rendah dan sederhana, kerajaan dan pihak swasta harus memainkan peranan masing-masing untuk memenuhi tanggungjawab sosial kepada rakyat. Malah pada masa kini, keperluan terhadap rumah mampu milik juga turut dibangkitkan oleh golongan berpendapatan sederhana akibat kenaikan kos sara hidup yang telah menyebabkan kemampuan golongan ini untuk memiliki rumah sendiri menjadi semakin sukar. Pada masa yang sama, mereka ini dianggap tidak layak untuk membeli rumah kos rendah yang ditawarkan berdasarkan pendapatan yang diperoleh. Terdapat pelbagai faktor yang mempengaruhi penawaran sesuatu perumahan seperti harga tanah, kos pengeluaran, objektif firma, jumlah penduduk, peruntukan kerajaan 
terhadap projek perumahan dan polisi kerajaan (Mulok dan Kogid 2008). Kajian berkaitan perumahan dan pemilikan rumah bukanlah perkara baharu di Malaysia kerana telah banyak kajian yang dilakukan untuk mengupas isu tersebut, misalnya oleh Morshidi et al. (1999), Mohd Razali (2001), Nor Aini dan Chamhuri (2003) dan Tan (2008).

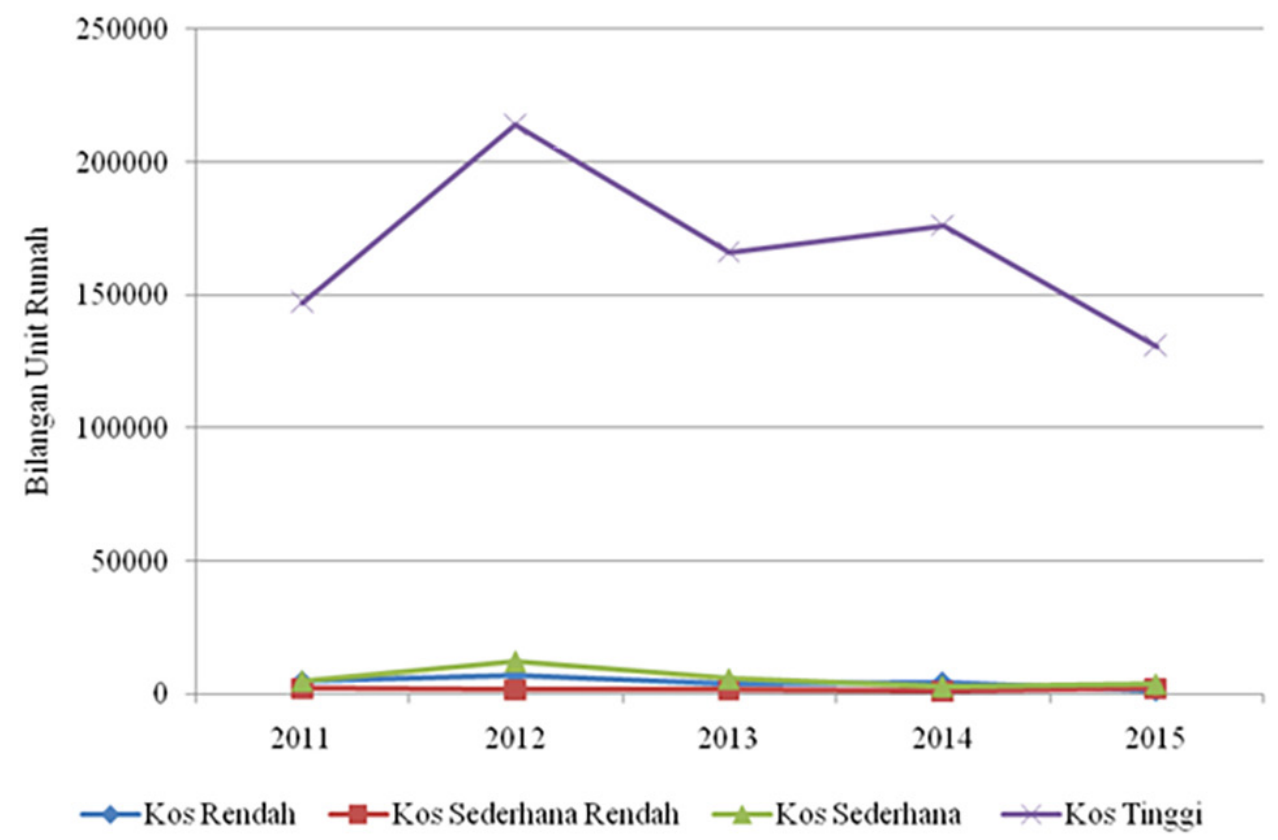

Rajah 2. Bilangan unit rumah yang diluluskan pembinaan kepada pemaju swasta mengikut kategori harga rumah, 2011-2015

Nota: Kos rendah (RM42,000 ke bawah); kos sederhana rendah (RM42,001-RM70,000); kos sederhana (RM70,001-RM100,000); kos tinggi (melebihi RM100,000)

Sumber: Ubah suai daripada data perangkaan Kementerian Kesejahteraan Bandar, Perumahan dan Kerajaan Tempatan (KPKT 2015)

Antara isu dan cabaran berkaitan perumahan mampu milik adalah penawaran perumahan mampu milik yang tidak sepadan dengan permintaan, kenaikan harga rumah di bandar-bandar utama, kekurangan perancangan dan pelaksanaan yang bersepadu, kekurangan penyelenggaraan perumahan awam serta kemudahan awam yang tidak mencukupi (Malaysia 2015). Isu-isu lain yang tidak kurang pentingnya adalah seperti penyediaan unit rumah yang mencukupi dan mampu dimiliki serta ketercapaian terhadap pemilikan rumah (ISIS 2013; Nor Malina dan Azrina 2012). Bagi memastikan sektor perumahan dalam negara mencapai pembangunan yang sihat dan terus menyumbang secara positif kepada pertumbuhan ekonomi negara dan kualiti hidup, beberapa isu penting perumahan harus diberi perhatian: 
- Kemampuan dan aksesibiliti rakyat untuk membeli atau menyewa rumah yang disediakan

- Permintaan yang melebihi penawaran bagi rumah kos rendah dan kos sederhana

- Kualiti rumah yang dibina

- Projek perumahan yang terbengkalai

- Pembangunan Projek Rumah Mampu Milik (PRMM) di lokasi yang tidak strategik

- Isu pengagihan PRMM

Kerajaan Malaysia sentiasa komited dalam program pembangunan perumahan, termasuk projek-projek pembinaan rumah kos rendah. Permintaan terhadap rumah kos rendah berkait rapat dengan pertambahan penduduk dan golongan berpendapatan rendah (Ahmad Ezanee et al. 2012) yang juga dimanifestasikan melalui pertambahan jumlah penduduk miskin bandar dan setinggan dari semasa ke semasa (Mohd Razali 1984). Hasil daripada itu, kerajaan mengambil langkah dengan mendirikan lebih banyak rumah kos rendah bagi menampung keperluan penduduk miskin. Dalam kajian separuh penggal Rancangan Malaysia ke-2 (1971-1975) sebagai contoh, tumpuan diberikan terhadap pembinaan rumah kos rendah bagi meningkatkan kehidupan golongan miskin, khususnya di kawasan bandar (Mohd Razali 1984).

Selain pihak kerajaan, pemaju swasta turut sama membina rumah-rumah kos rendah sebagai salah satu tanggungjawab sosial mereka di samping polisi kerajaan yang menetapkan kuota 30 peratus rumah kos rendah mestilah dibina oleh pemaju swasta dalam projek perumahan yang mereka bangunkan (Abdul-Aziz 2007; REHDA 2008). Namun, terdapat pelbagai cabaran yang dihadapi oleh pemaju swasta seperti kenaikan kadar hutang akibat kenaikan kos bahan mentah serta upah pekerja dan harga tanah yang semakin meningkat. Kos pembinaan rumah kos rendah adalah lebih tinggi daripada harga rumah yang telah ditetapkan oleh kerajaan. Akibatnya, pemaju swasta terpaksa menanggung kos yang lebih tinggi berbanding keuntungan yang mereka peroleh (Ghani dan Lee 1997).

Jurang antara permintaan dengan penawaran perumahan mampu milik masih wujud disebabkan oleh perubahan sosioekonomi, pembandaran dan perkembangan struktur penduduk. Berdasarkan laporan daripada Jabatan Perangkaan Malaysia (2014), kira-kira 66.1 peratus daripada isi rumah berpendapatan 40 peratus terendah (B40) di bandar tinggal di rumah sendiri dan 30.6 peratus tinggal di rumah sewa. Sebahagian besar isi rumah di kawasan bandar tinggal dalam rumah 
yang mempunyai bilangan isi rumah yang ramai, iaitu secara purata lebih daripada dua orang dalam setiap bilik. Pada tahun 2014, terdapat sebanyak 63,662 isi rumah yang terdiri daripada 273,381 ahli keluarga tinggal di kawasan setinggan, majoritinya adalah di Sabah, Sarawak, Johor dan Pulau Pinang (Malaysia 2015). Kajian yang dijalankan oleh Khazanah Research Insitute mendapati bahawa isi rumah di kebanyakan negeri di Malaysia tidak mempunyai kemampuan untuk memiliki rumah. Harga rumah didapati 4.4 kali ganda lebih tinggi berbanding purata gaji tahunan dan harga ini sangat mahal atau sangat tidak mampu dimiliki berdasarkan piawaian antarabangsa (Khazanah Research Institute 2015). Jadual 3 menunjukkan indeks kemampuan perumahan mengikut negeri di Malaysia. Dapatan daripada Jadual 3 ini menunjukkan banyak negeri di Malaysia mencatatkan indeks kemampuan pada tahap sangat tinggi ketidakmampuan (severly unaffordable) dan sangat tidak berkemampuan (seriously unaffordable).

Jadual 3. Indeks kemampuan perumahan mengikut negeri di Malaysia

\begin{tabular}{lcl}
\hline Negeri & Indeks kemampuan & Kategori indeks \\
\hline Terengganu & 5.5 & 5.1 dan ke atas \\
Kuala Lumpur & 5.4 & Sangat tinggi ketidakmampuan \\
Pulau Pinang & 5.2 & \\
Sabah & 5.1 & \\
Pahang & 4.9 & $4.1-5.0$ \\
Kelantan & 4.8 & Sangat tidak berkemampuan \\
Malaysia & 4.4 & \\
Perak & 4.3 & \\
Perlis & 4.3 & \\
Johor & 4.2 & $3.1-4.0$ \\
Selangor & 4.0 & Tidak berkemampuan sederhana \\
Negeri Sembilan & 3.8 & \\
Sarawak & 3.6 & 3.0 dan ke bawah \\
Kedah & 3.4 & Berkemampuan \\
Melaka & 3.0 & \\
& & \\
\hline
\end{tabular}

Sumber: Khazanah Research Institute $(2015,9)$

Kajian-kajian terdahulu turut mendapati bahawa terdapat pelbagai isu dalam pembinaan rumah kos rendah, termasuk kepuasan terhadap rumah yang dibina. Aspek kepuasan penghuni rumah merupakan pandangan subjektif penduduk yang menggambarkan perasaan mereka terhadap rumah yang didiami. Pandangan ini boleh menjadi petunjuk penting dalam menilai peranan perumahan dalam kesejahteraan hidup penduduk. Beberapa pengkaji seperti Husna dan Nurizan (1987), Djebarni dan Al-Abed (2000), Ogu (2002), Afon (2006), Kellekci dan Berkoz (2006), Abdul Ghani (2008) dan Lee dan Park (2010) menilai kepuasan 
terhadap rumah yang didiami berdasarkan aspek unit rumah dan persekitaran. Puddiffot (1994) pula menyatakan bahawa tahap kepuasan terhadap rumah yang didiami dinilai dengan mengambil kira aspek sosial, komersial, perkhidmatan yang disediakan, persekitaran fizikal termasuk akauntabiliti, keberkesanan dan kecekapan penggubal dasar dalam menyediakan perumahan. Menurut McCray dan Day (1977) dan Tan (2011), perumahan yang dapat memenuhi keperluan dan mencapai piawaian yang dikehendaki oleh penghuninya akan dapat meningkatkan tahap kepuasan penghuni terhadap rumah yang dimiliki. Di samping itu, kepuasan perumahan juga berkait dengan perasaan seseorang terhadap persekitaran dan fizikal perumahan, dan ia berbeza mengikut demografi dan sosioekonomi penghuni perumahan itu (Kellekci dan Berkoz 2006).

\section{Perumahan dan Tekanan Perumahan: Sorotan Literatur}

Rumah merupakan satu keperluan asas penduduk yang bukan sahaja memberi perlindungan fizikal kepada penghuninya tetapi juga mempengaruhi kesejahteraan hidup penduduk. Peningkatan kos perbelanjaan rumah dan harga rumah telah menarik banyak kajian berkaitan kemampuan perumahan dan tekanan perumahan. Kemampuan perumahan secara amnya boleh ditakrifkan sebagai kos yang mampu ditanggung oleh penghuni dalam memiliki rumah yang mempunyai kemudahan asas yang mencukupi serta tahap ketercapaian kepada peluang pekerjaan dan perkhidmatan komuniti (Disney 2006). Menurut Stone, Burke dan Ralston (2011) dan Leishman dan Rowley (2012), kemampuan yang lebih luas meliputi piawaian perumahan dan kesesuaian, ekonomi serta isu-isu sosial dan kejiranan. Oleh itu, gambaran kemampuan perumahan seharusnya melampaui bukan sahaja pengalaman kemampuan membiayai kos perumahan tetapi juga persepsi penghuni terhadap kesan kos perumahan kepada kualiti hidup mereka. Baqutayan, Arifin dan Raji (2015) mendapati bahawa terdapat tiga isu utama perumahan yang dihadapi oleh kumpulan berpendapatan sederhana, iaitu harga rumah, pinjaman perumahan dan dasar skim perumahan.

Konsep tekanan perumahan telah menarik minat pembuat dasar sejak pertengahan tahun 1990-an bagi memahami dan menyediakan petunjuk kepada kemampuan perumahan untuk digunakan dalam pembentukan polisi dalam menyokong strategi perumahan. Hal ini adalah kerana tekanan perumahan banyak dikaitkan dengan kemampuan penduduk untuk memiliki rumah. Gabriel et al. (2005) mentakrifkan tekanan perumahan sebagai satu istilah umum bagi menunjukkan kesan negatif kepada isi rumah apabila pendapatan yang dimiliki tidak mencukupi untuk mendapatkan rumah yang sesuai. Ia merangkumi pelbagai keadaan kewangan, termasuk kekangan deposit. Gabriel et al. (2005) juga menyatakan bahawa tekanan perumahan boleh disebabkan oleh isu-isu seperti kesesakan, keadaan perumahan 
yang tidak selamat dan kualiti kemudahan yang disediakan. Menurut Rowley dan Ong (2012), terdapat bukti yang menunjukkan tekanan perumahan tidak hanya disebabkan oleh kekangan kewangan, tetapi juga disebabkan oleh faktor-faktor lain seperti kualiti binaan rumah yang rendah, kawasan perumahan yang kurang sumber ekonomi dan pendidikan serta kemudahan dan kejiranan yang tidak berkualiti. Hal ini menyebabkan terdapat keluarga yang memilih untuk menanggung beban kos perumahan yang tinggi bagi mendapatkan rumah dan kejiranan yang berkualiti. Justeru, pemilihan rumah yang dibuat ternyata boleh memberi kesan terhadap kesejahteraan hidup mereka, khususnya dalam kalangan penduduk berpendapatan rendah dan sederhana yang mempunyai sumber kewangan yang terhad untuk memiliki rumah idaman.

Banyak kajian didapati memfokus kepada pemboleh ubah kekangan kewangan sebagai penyebab kepada tekanan perumahan. Hulse et al. (2010) mengkaji indikator kekangan kewangan terhadap perbelanjaan isi rumah seperti ketidakupayaan untuk membayar bil utiliti tepat pada masanya serta terpaksa mendapatkan bantuan kewangan daripada keluarga dan rakan sebagai petunjuk kepada tekanan perumahan. Yates dan Milligan (2007) pula menjelaskan bahawa isi rumah dianggap mengalami tekanan perumahan apabila menghadapi kesukaran yang tinggi daripada segi kewangan dalam menguruskan perbelanjaan isi rumah. Menurut Vidyattama, Tanton dan Nepal (2011), isi rumah dikatakan mengalami tekanan perumahan apabila membelanjakan lebih 30 peratus daripada pendapatan untuk kos mengurus perbelanjaan rumah dan golongan ini merupakan golongan yang berada dalam kelompok B40 daripada segi pendapatan. Karantonis (2009) menyatakan bahawa peningkatan harga dan sewa rumah boleh mendorong kepada tekanan perumahan. Begitu juga dengan kajian $\mathrm{Vu}$ (2007) tentang kesan kenaikan sewa rumah di Australia yang boleh menyebabkan tekanan perumahan, khususnya di Queensland yang mempunyai kadar tekanan perumahan paling tinggi diikuti oleh New South Wales, Victoria, Tasmania, Australia Selatan dan Australia Barat. Hal ini disebabkan oleh perbezaan dalam pendapatan boleh guna dan sewa antara wilayah.

Tekanan perumahan juga disebabkan oleh faktor-faktor lain seperti kualiti rumah, persekitaran kejiranan, lokasi perumahan dan tahap keselamatan. Baqutayan (2014) dalam kajiannya mendapati bahawa terdapat pelbagai faktor yang boleh menyumbang kepada tekanan perumahan dalam kalangan golongan berpendapatan rendah dan sederhana, antaranya adalah perbezaan dalam pendapatan boleh guna; rumah yang tidak selamat; tinggal jauh dari tempat kerja, keluarga atau sistem sokongan lain; harga sewa rumah yang tinggi; tinggal jauh dari klinik/hospital, sekolah, universiti/kolej; rumah yang terlalu sesak atau dikongsi dengan orang lain; dan perbelanjaan yang lebih untuk pengangkutan. Penduduk berpendapatan 
rendah dan sederhana merupakan golongan yang menerima kesan yang ketara apabila berlakunya kenaikan harga atau sewa rumah. Tambahan pula, masalah penawaran perumahan yang sesuai (daripada segi harga dan kualiti perumahan) serta peningkatan kos rumah telah menjadi isu yang serius di kebanyakan negara termasuk Malaysia, khususnya di kawasan bandar-bandar besar. Kesan rantaian akibat masalah perumahan (kuantiti, kualiti dan kos) turut memberi kesan terhadap psikologi dan sosial penduduk dan seterusnya menjejaskan kesejahteraan hidup golongan ini. Smith, Searle dan Cook (2009) misalnya telah mengenal pasti dimensi kesejahteraan hidup dan penyertaan sosial, ekonomi dan kestabilan kewangan sebagai aspek yang semakin kritikal yang menuntut campur tangan kerajaan dalam dasar perumahan pada masa kini.

Menurut Bonnefoy (2007), rumah yang menjadi tempat kediaman bertindak seperti "sampul yang melindungi penghuni secara fizikal dan psikologi" yang boleh mempengaruhi perkembangan dan saling hubungan yang erat antara penghuninya. Oleh itu, rumah bukan sekadar memberi perlindungan fizikal tetapi juga mempengaruhi tahap kesejahteraan hidup individu. Menurut Quigley dan Raphael (2004), keprihatinan terhadap kemampuan memiliki rumah disebabkan oleh dua faktor: (1) perbelanjaan/kos perumahan menjadi item perbelanjaan paling besar dalam bajet kebanyakan keluarga dan individu, dan sekiranya berlaku perubahan (walaupun kecil) terhadap harga atau sewa rumah (selalunya melibatkan kenaikan), ia akan memberi kesan yang besar terhadap perbelanjaan bukan-perumahan dan kesejahteraan hidup isi rumah; (2) kebanyakan rumah di bandar metropolitan besar telah mengalami kenaikan harga, begitu juga dengan kadar sewa rumah, dan trend ini dijangka berterusan. Pada hari ini kos perumahan telah menjadi semakin mahal dan membebankan, khususnya di kawasan bandar yang menjadi tumpuan penduduk.

Kajian berkaitan tekanan perumahan kebanyakannya melihat tekanan perumahan daripada dimensi yang sempit, iaitu hanya merujuk kepada kekangan kewangan yang diukur berdasarkan kepada petunjuk kemampuan perumahan (Nepal et al. 2008; Nepal, Tanton dan Harding 2010). Penduduk mengalami tekanan perumahan yang memberi kesan kepada kesihatan mental apabila mereka menghadapi kesukaran untuk membuat bayaran rumah. Namun demikian, kajian ini juga mendapati bahawa faktor-faktor seperti kesesakan penduduk, jaminan milikan rumah, keselamatan, hubungan dengan jiran dan tuan rumah, kekurangan kemudahan dalam rumah dan persekitaran kejiranan yang tidak memuaskan juga boleh mencetuskan tekanan dan masalah kesihatan mental (Sandel dan Wright 2006; Li dan Liu 2018). Tekanan juga boleh dicetuskan oleh keadaan yang merimaskan setiap hari seperti pergaduhan antara jiran, kebimbangan terhadap kemalangan yang mungkin berlaku, ketakutan terhadap gangguan fizikal, keperluan untuk 
berkompromi daripada segi privasi serta kekurangan kawalan dan rasa autonomi terhadap kediaman.

Sandel dan Wright (2006) mengklasifikasikan tekanan perumahan kepada dua jenis, iaitu tekanan fizikal dan tekanan emosi. Tekanan fizikal termasuk kesan daripada kualiti perumahan yang rendah dan ciri-ciri tempat kediaman, sementara tekanan emosi merupakan kesan daripada kesesakan, kekurangan kawalan, tempoh pegangan/milikan rumah dan kos perumahan. Kualiti perumahan yang di bawah piawaian yang ditetapkan, pencemaran bunyi, struktur rumah yang kurang memuaskan, kehadiran makhluk perosak, kelembapan dan kekurangan privasi juga boleh menyumbang kepada tekanan perumahan.

Golongan berpendapatan rendah terpaksa memilih perumahan yang berkualiti rendah kerana harganya yang lebih murah. Malah terdapat golongan yang terpaksa menanggung kos pengangkutan ke tempat kerja yang tinggi kerana lokasi rumah yang kurang sesuai. Oleh itu, tekanan perumahan tidak hanya terhad kepada faktorfaktor kekangan kewangan sahaja tetapi perlu diperluaskan merangkumi faktorfaktor bukan ekonomi yang lain. Rajah 3 menunjukkan kerangka konseptual kajian yang mana perumahan dalam konteks kajian ini dilihat sebagai unit kediaman atau rumah dan persekitaran kejiranan perumahan. Persekitaran kejiranan dalam konteks kajian ini merangkumi persekitaran fizikal, sosial dan alam sekitar. Beberapa item ekonomi dan bukan ekonomi telah disenaraikan untuk mendapatkan pandangan dan pengalaman subjektif responden terhadap faktor-faktor yang menyumbang kepada tekanan perumahan.

Jelas bahawa terdapat banyak isu perumahan yang boleh mencetus kepada tekanan perumahan dan memberi kesan terhadap kesejahteraan hidup penduduk. Namun, yang menjadi cabaran pada masa kini adalah untuk menentukan dan menjelaskan faktor-faktor perumahan yang boleh mencetuskan tekanan perumahan kepada penduduk. Selain faktor kewangan, kualiti rumah yang dibina juga merupakan aspek yang tidak boleh diabaikan yang boleh membawa kepada tekanan perumahan (Stone 2006). Perumahan yang mampu menawarkan kelebihan daripada segi keselamatan, kesihatan, kegembiraan dan kesejahteraan ekonomi dapat menyumbang kepada kualiti hidup yang lebih baik. 




Rajah 3. Kerangka konseptual kajian

\section{Metodologi dan Lokasi Kajian}

Kajian ini melibatkan pengumpulan data primer melalui edaran borang soal selidik dalam kalangan penduduk di beberapa kawasan perumahan kos rendah dan sederhana rendah di Pulau Pinang. Empat kawasan terlibat adalah George Town, Bayan Baru, Gelugor dan Bukit Jambul yang merupakan antara kawasan bandar yang pesat berkembang di Pulau Pinang. Pemilihan responden dibuat secara rawak berdasarkan kepada kesediaan dan persetujuan mereka untuk terlibat dengan kajian ini. Seramai 400 responden terlibat dalam kajian ini dengan pecahan 100 responden bagi setiap kawasan kajian. Borang soal selidik telah diedarkan kepada ketua isi rumah dan ditadbir oleh penyelidik dan pembantu penyelidik yang terlatih untuk membantu responden melengkapkan borang soal selidik tersebut secara bersemuka. Secara purata, responden mengambil masa antara 30 hingga 
40 minit untuk melengkapkan borang soal selidik. Data yang dikutip melalui borang soal selidik telah dianalisis menggunakan SPSS versi 22 dan dibincangkan secara deskriptif tetapi kritis dalam menilai pandangan subjektif responden terhadap faktor-faktor yang menyumbang kepada tekanan perumahan di kawasan perumahan mereka.

\section{Perbincangan Dapatan Kajian}

Jadual 4 menunjukkan latar belakang pemilikan rumah responden yang terlibat dalam kajian ini. Majoriti responden (55.0 peratus) merupakan pemilik rumah dan hanya 22.8 peratus merupakan penyewa manakala 22.3 peratus mendiami rumah milik keluarga. Sebahagian besar responden telah mendiami rumah tersebut lebih daripada 15 tahun. Daripada segi kategori perumahan, 81 peratus mendiami perumahan kos rendah dan 19 peratus perumahan kos sederhana. Kajian yang dijalankan mendapati bahawa 97 peratus daripada responden memperuntukkan lebih daripada 30 peratus daripada pendapatan mereka untuk perbelanjaan rumah (Jadual 5). Walaupun terdapat beberapa kritikan tentang ukuran yang digunakan dalam menentukan tekanan perumahan, pendekatan nisbah merupakan ukuran yang paling luas digunakan bagi mengukur tekanan perumahan (Stone 2006). Ukuran dibuat berdasarkan nisbah kos perumahan dengan pendapatan pada tahap 30 peratus yang menjadi penanda aras. Isi rumah ditakrifkan sebagai berada dalam tekanan perumahan apabila ia membayar lebih 30 peratus daripada pendapatan kasar untuk menanggung kos perumahan dan pendapatannya adalah antara 40 peratus terendah daripada semua isi rumah (peraturan 30:40). Namun, ukuran kekangan kewangan semata-mata tidak dapat menjelaskan kesan tekanan perumahan terhadap penghuni dan kesejahteraan hidup mereka.

Jadual 4. Latar belakang pemilikan rumah responden kajian $(\mathrm{N}=400)$

\begin{tabular}{llrc}
\hline Ciri-ciri & & Jumlah & Peratus \\
\hline Kategori perumahan & Rumah kos rendah & 324 & 81.0 \\
& Rumah kos sederhana rendah & 76 & 19.0 \\
Jenis rumah & Rumah flat/pangsa tanpa lif (5 tingkat) & 142 & 35.5 \\
& Rumah flat/pangsa (high rise) & 200 & 50.0 \\
& Rumah kluster & 58 & 14.5 \\
Lokasi perumahan & Flat Jalan Kedah, George Town & 100 & 25.0 \\
& Bukit Gedung, Bayan Baru & 100 & 25.0 \\
& Tun Sardon, Gelugor & 100 & 25.0 \\
& Taman Bukit Jambul, Bukit Jambul & 100 & 25.0 \\
\hline & & & (bersambung)
\end{tabular}


Jadual 4 (sambungan)

\begin{tabular}{|c|c|c|c|}
\hline Ciri-ciri & & Jumlah & Peratus \\
\hline \multirow[t]{3}{*}{ Status pemilikan rumah } & Sendiri & 220 & 55.0 \\
\hline & Sewa & 91 & 22.8 \\
\hline & Milik keluarga & 89 & 22.3 \\
\hline \multirow[t]{5}{*}{ Tempoh pemilikan rumah } & Kurang 1 tahun & 14 & 3.5 \\
\hline & $1-5$ tahun & 52 & 13.0 \\
\hline & 6-10 tahun & 35 & 8.8 \\
\hline & 11-15 tahun & 16 & 4.0 \\
\hline & Lebih 15 tahun & 283 & 70.8 \\
\hline \multirow{6}{*}{$\begin{array}{l}\text { Pendapatan sebulan ketua } \\
\text { isi rumah }\end{array}$} & Kurang RM1,000 & 39 & 9.8 \\
\hline & RM1,000-RM2,500 & 181 & 45.3 \\
\hline & RM2,501-RM3,500 & 126 & 31.5 \\
\hline & RM3,501- RM4,500 & 31 & 7.8 \\
\hline & RM4,501- RM5,500 & 15 & 3.8 \\
\hline & Lebih RM5,500 & 8 & 2.0 \\
\hline \multirow{6}{*}{$\begin{array}{l}\text { Pendapatan sebulan } \\
\text { isi rumah }\end{array}$} & Kurang RM1,000 & 13 & 3.3 \\
\hline & RM1,000-RM3,000 & 87 & 21.8 \\
\hline & RM3,001-RM5,000 & 181 & 45.3 \\
\hline & RM5,001-RM7,000 & 92 & 23.0 \\
\hline & RM7,001-RM9,000 & 20 & 5.0 \\
\hline & Lebih RM9,000 & 7 & 1.8 \\
\hline
\end{tabular}

Jadual 5. Anggaran peruntukan mengurus kos perumahan mengikut status milikan rumah

\begin{tabular}{lccccccc}
\hline \multirow{2}{*}{ Status pemilikan rumah } & \multicolumn{2}{c}{$\begin{array}{c}\text { Kurang 30\% daripada } \\
\text { jumlah pendapatan }\end{array}$} & & \multicolumn{2}{c}{$\begin{array}{c}\text { Lebih 30\% daripada } \\
\text { jumlah pendapatan }\end{array}$} & Jumlah \\
\cline { 2 - 3 } & \multicolumn{2}{c}{ Bil. } & jo & & Bil. & \% & \\
\hline Sendiri & 7 & 3.2 & & 213 & 96.8 & 220 \\
Sewa & 5 & 5.5 & & 86 & 94.5 & 91 \\
Milik keluarga & 0 & - & & 89 & 100.0 & 89 \\
\hline Jumlah & 12 & 3.0 & & 388 & 97.0 & 400 \\
\hline
\end{tabular}

Hasil dapatan kajian (lihat Jadual 6) menunjukkan hanya 28.5 peratus responden yang menyatakan faktor kos perumahan (sama ada bayaran pinjaman perumahan atau sewa) sebagai faktor penyumbang kepada tekanan perumahan berbanding hampir 72 peratus yang menyatakan mereka tidak tertekan dengan kos perumahan. Sebaliknya, majoriti responden (lebih 50 peratus) melaporkan mereka merasa tertekan disebabkan oleh faktor kualiti rumah dan persekitaran seperti 
kesesakan penduduk, kemudahan tempat letak kereta, kos pengangkutan, tahap kebersihan, pencemaran (udara dan bau), keselesaan terma dan keselamatan. Hal ini menunjukkan bahawa faktor utama yang menyumbang kepada tekanan perumahan dalam kalangan penduduk di perumahan kos rendah dan sederhana rendah bukan hanya faktor ekonomi (kemampuan) tetapi lebih kepada faktor yang berkaitan dengan kualiti persekitaran dan kualiti perumahan di lokasi kajian. Walaupun faktor ekonomi tidak dianggap oleh kebanyakan responden sebagai faktor penyebab kepada tekanan perumahan, namun majoriti responden, iaitu tidak kurang daripada 70 peratus, bersetuju bahawa kos perbelanjaan rumah (kos rumah termasuk bayaran pinjaman/sewa, kos bayaran utiliti, penyelenggaraan, cukai dan hal-hal lain berkaitan perumahan) pada dasarnya adalah membebankan. Selain itu, walaupun lokasi perumahan adalah di dalam bandar namun tidak kurang daripada 62 peratus responden kajian menyatakan kos pengangkutan yang terpaksa ditanggung memberi tekanan kepada mereka. Kajian oleh Dunn (2002) melaporkan rungutan responden terhadap kos pengangkutan yang dianggap sebagai penyumbang kepada tekanan perumahan; hal ini mengambil kira faktor jarak antara rumah dengan tempat kerja. Namun, kajian ini mendapati bahawa hanya 25.2 peratus responden merasa tertekan dengan jarak ke tempat kerja dan 7.5 peratus lagi adalah faktor lokasi perumahan. Hal ini menunjukkan bahawa aspek jarak ke tempat kerja dan lokasi perumahan tidak menyumbang kepada tekanan perumahan, sebaliknya secara tersirat, kenaikan kos sumber bahan api (petrol) ternyata memberi tekanan dan menambah beban kewangan kepada golongan ini.

Jadual 6. Faktor-faktor yang menyumbang kepada tekanan rumah

\begin{tabular}{|c|c|c|c|c|c|}
\hline \multirow{3}{*}{ Item } & \multicolumn{4}{|c|}{ Respons YA } & \multirow{3}{*}{$\begin{array}{c}\begin{array}{c}\text { Jumlah }(\%) \\
(\mathrm{n}=400)\end{array} \\
\text { Bil. (\%) }\end{array}$} \\
\hline & \multicolumn{2}{|c|}{$\begin{array}{c}\text { Kos rendah } \\
\quad(n=324)\end{array}$} & \multicolumn{2}{|c|}{$\begin{array}{c}\text { Kos sederhana } \\
\text { rendah } \\
(\mathrm{n}=76) \\
\end{array}$} & \\
\hline & Bil. & $\%$ & Bil. & $\%$ & \\
\hline Saiz dan keluasan rumah & 126 & 38.9 & 16 & 21.1 & $142(35.5)$ \\
\hline Bilangan penghuni rumah & 118 & 36.4 & 19 & 25.0 & $137(34.2)$ \\
\hline Jarak ke sekolah & 15 & 4.6 & 9 & 11.8 & $24(6.0)$ \\
\hline Jarak ke tempat kerja & 88 & 27.2 & 13 & 17.1 & $101(25.2)$ \\
\hline Jarak ke tempat membeli-belah & 8 & 2.5 & 11 & 14.5 & $19(4.7)$ \\
\hline Kos rumah (pinjaman/sewa) & 86 & 26.5 & 28 & 36.8 & $114(28.5)$ \\
\hline Kualiti rumah dan bahan binaan & 90 & 27.8 & 13 & 17.1 & $103(25.7)$ \\
\hline Liputan perkhidmatan telekomunikasi & 3 & 0.9 & 9 & 11.9 & $12(3.0)$ \\
\hline $\begin{array}{l}\text { Tahap ketercapaian kepada perkhidmatan } \\
\text { (hospital/bank/pejabat pos) }\end{array}$ & 4 & 1.2 & 10 & 13.2 & $14(3.5)$ \\
\hline
\end{tabular}


Jadual 6 (sambungan)

\begin{tabular}{|c|c|c|c|c|c|}
\hline \multirow{3}{*}{ Item } & \multicolumn{4}{|c|}{ Respons YA } & \multirow{3}{*}{$\begin{array}{c}\begin{array}{c}\text { Jumlah (\%) } \\
(\mathrm{n}=\mathbf{4 0 0})\end{array} \\
\text { Bil. (\%) }\end{array}$} \\
\hline & \multicolumn{2}{|c|}{$\begin{array}{l}\text { Kos rendah } \\
\quad(n=324)\end{array}$} & \multicolumn{2}{|c|}{$\begin{array}{c}\text { Kos sederhana } \\
\text { rendah } \\
(\mathrm{n}=76)\end{array}$} & \\
\hline & Bil. & $\%$ & Bil. & $\%$ & \\
\hline $\begin{array}{l}\text { Jumlah/kepadatan penduduk (kesesakan } \\
\text { penduduk) }\end{array}$ & 304 & 93.8 & 11 & 14.5 & 315 (78.7) \\
\hline Kos pengangkutan & 260 & 80.2 & 13 & 17.1 & $273(68.2)$ \\
\hline Tahap kebersihan & 226 & 69.8 & 39 & 51.3 & $265(66.2)$ \\
\hline Pencemaran (udara, bau) & 222 & 68.5 & 37 & 48.7 & $259(64.7)$ \\
\hline Keselesaan terma (suhu, edaran udara) & 213 & 65.7 & 11 & 14.5 & $224(56.0)$ \\
\hline Ancaman kesihatan & 94 & 29.0 & 21 & 27.6 & $115(28.0)$ \\
\hline Tahap privasi & 42 & 12.9 & 13 & 17.1 & $55(13.7)$ \\
\hline Tahap keselamatan & 176 & 54.3 & 37 & 48.7 & $213(53.2)$ \\
\hline Kemudahan tempat letak kereta & 267 & 82.4 & 40 & 52.6 & $300(75.0)$ \\
\hline Lokasi perumahan & 20 & 6.2 & 10 & 13.2 & $30(7.5)$ \\
\hline Hubungan kejiranan & 48 & 14.8 & 7 & 9.2 & $55(13.7)$ \\
\hline
\end{tabular}

Nota: Nombor yang dihitamkan bermaksud respons yang diterima adalah melebihi 50 peratus

Berdasarkan maklumat pendapatan ketua isi rumah (Jadual 4), didapati tidak kurang daripada 86 peratus merupakan golongan berpendapatan rendah dan selebihnya dalam kategori pertengahan. Namun, didapati pendapatan isi rumah menunjukkan bahawa majoriti responden berada dalam kategori pendapatan antara RM3,001 hingga RM5,000 sebulan dan tidak kurang 30 peratus responden dalam kategori pendapatan lebih daripada RM5,000 sebulan. Hal ini menunjukkan bahawa golongan ini telah membina kekayaan dan sumber pendapatan mereka melalui masa yang membolehkan mereka terus mengekalkan pemilikan perumahan dan membiayai kos perumahan. Berdasarkan kajian yang dijalankan ini, didapati 32.3 peratus responden masih perlu membuat bayaran pinjaman bank atau sewa sementara 67.7 peratus telah melangsaikan pinjaman masing-masing. Keadaan ini menyebabkan golongan ini tidak menghadapi kesukaran kewangan untuk menguruskan kos perumahan. Namun demikian, didapati golongan penyewa ternyata lebih banyak mengalami tekanan dalam mengurus kos perumahan berbanding pemilik dan mereka yang mendiami rumah milik keluarga (Jadual 7). Menurut Rowley dan Ong (2012), walaupun tekanan perumahan agak tinggi dalam kalangan penyewa, namun ia juga telah menjadi semakin ketara dalam kalangan pembeli (pemilik rumah), terutama pembeli yang belum menyelesaikan bayaran pinjaman mereka. 
Jadual 7. Tekanan perumahan mengikut status pemilikan rumah

\begin{tabular}{|c|c|c|c|c|c|}
\hline \multirow{3}{*}{ Status pemilikan rumah } & \multicolumn{5}{|c|}{ Tekanan perumahan } \\
\hline & \multicolumn{2}{|c|}{ Ya } & \multicolumn{2}{|c|}{ Tidak } & \multirow{2}{*}{ Jumlah } \\
\hline & Bil. & $\%$ & Bil. & $\%$ & \\
\hline Sendiri & 36 & 16.4 & 184 & 83.6 & 220 \\
\hline Sewa & 74 & 81.3 & 17 & 18.7 & 91 \\
\hline Milik keluarga & 4 & 4.5 & 85 & 95.5 & 89 \\
\hline
\end{tabular}

Rajah 4 menunjukkan faktor-faktor berkaitan perumahan yang menyebabkan tekanan kepada responden kajian. Faktor ekonomi pada dasarnya bukan penyebab kepada tekanan perumahan dalam kalangan penduduk di kawasan perumahan kos rendah dan sederhana rendah yang terlibat dalam kajian ini. Sebaliknya, faktor bukan ekonomi seperti kesesakan dan masalah tempat letak kereta, kebersihan dan pencemaran di kawasan perumahan merupakan faktor utama yang menyumbang kepada tekanan perumahan yang mencatatkan respons tidak kurang daripada 60 peratus. Kawasan perumahan dalam bandar lazimnya akan mengalami masalah kesesakan akibat binaan yang padat dan jumlah penduduk yang ramai. Cantarero dan Potter (2012) menyatakan bahawa faktor kesesakan dan impaknya terhadap psikologi penduduk boleh menyumbang kepada tekanan perumahan. Kesesakan boleh menimbulkan kesan negatif terhadap kesihatan mental penduduk. Walaupun faktor kesesakan dilihat sebagai masalah kepada penghuni di lokasi kajian, namun didapati bahawa hubungan sosial dalam kalangan penduduk adalah baik. Selain itu, aspek jarak, tahap ketercapaian kepada perkhidmatan dan lokasi perumahan ternyata memberi kelebihan kepada penghuni di kawasan kajian kerana kedudukan kawasan perumahan adalah di dalam bandar. Hal ini membolehkan akses yang tinggi kepada pelbagai kemudahan perkhidmatan. Namun, apabila kawasan bandar semakin berkembang, kawasan perumahan juga semakin terhimpit dengan kesesakan dan menjejaskan kualiti alam sekitar. Masalah pencemaran seperti pencemaran bunyi dan udara serta keselesaan terma telah dilaporkan oleh responden kajian sebagai faktor yang menyumbang kepada tekanan perumahan.

Jadual 8 menunjukkan reaksi responden terhadap semua item mengikut lokasi perumahan. Didapati kawasan perumahan di Bukit Gedung mempunyai lebih banyak item perumahan yang menyumbang kepada tekanan perumahan berbanding kawasan perumahan yang lain. Walaupun jenis perumahan di Bukit Gedung merupakan perumahan kluster yang selalunya lebih digemari oleh pembeli, namun responden di kawasan perumahan ini lebih banyak melaporkan kekurangan yang dialami berbanding kawasan perumahan yang lain. Sementara itu, Jadual 9 menggariskan masalah-masalah yang dihadapi oleh responden di lokasi perumahan 
mereka. Kedudukan perumahan dalam bandar dan hampir dengan kawasan perindustrian juga turut membawa kesan negatif daripada segi pencemaran alam sekitar (bunyi bising dan udara yang kurang bersih) dan ditambah pula dengan peningkatan kehadiran warga asing yang ramai. Keadaan ini telah menyebabkan timbulnya rasa kurang senang dan kurang selamat dalam kalangan penduduk tempatan.

Jadual 8. Faktor perumahan yang memberi tekanan mengikut lokasi responden $(\mathrm{n}=100)$

\begin{tabular}{|c|c|c|c|c|c|c|c|c|}
\hline \multirow[t]{2}{*}{ Faktor perumahan } & \multicolumn{2}{|c|}{ 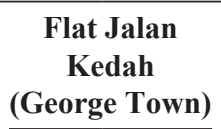 } & \multicolumn{2}{|c|}{$\begin{array}{l}\text { Bukit Gedung } \\
\text { (Bayan Baru) }\end{array}$} & \multicolumn{2}{|c|}{$\begin{array}{c}\text { Tun Sardon } \\
\text { (Gelugor) }\end{array}$} & \multicolumn{2}{|c|}{$\begin{array}{c}\text { Flat Bukit } \\
\text { Jambul } \\
\text { (Bukit Jambul) } \\
\end{array}$} \\
\hline & Ya & Tidak & Ya & Tidak & Ya & Tidak & Ya & Tidak \\
\hline Saiz dan keluasan rumah & 25 & 75 & 86 & 14 & 28 & 72 & 3 & 97 \\
\hline Bilangan penghuni rumah & 29 & 71 & 74 & 26 & 27 & 73 & 7 & 93 \\
\hline Jarak ke sekolah & 15 & 85 & 8 & 92 & 1 & 99 & 0 & 100 \\
\hline Jarak ke tempat kerja & 23 & 77 & 26 & 74 & 17 & 83 & 35 & 65 \\
\hline Jarak ke tempat membeli-belah & 16 & 84 & 1 & 99 & 2 & 98 & 0 & 100 \\
\hline Kos rumah (pinjaman/sewa) & 33 & 67 & 19 & 81 & 27 & 73 & 35 & 65 \\
\hline $\begin{array}{l}\text { Kualiti rumah dan bahan } \\
\text { binaan }\end{array}$ & 19 & 81 & 63 & 37 & 20 & 80 & 1 & 99 \\
\hline $\begin{array}{l}\text { Liputan perkhidmatan } \\
\text { telekomunikasi }\end{array}$ & 11 & 89 & 0 & 100 & 1 & 99 & 0 & 100 \\
\hline $\begin{array}{l}\text { Tahap ketercapaian kepada } \\
\text { perkhidmatan (hospital/bank/ } \\
\text { pejabat pos) }\end{array}$ & 13 & 87 & 0 & 100 & 1 & 99 & 0 & 100 \\
\hline $\begin{array}{l}\text { Kesesakan/kepadatan } \\
\text { penduduk }\end{array}$ & 17 & 83 & 98 & 2 & 100 & 0 & 100 & 0 \\
\hline Kos pengangkutan & 19 & 81 & 80 & 20 & 89 & 11 & 85 & 15 \\
\hline Tahap kebersihan & 55 & 45 & 95 & 5 & 77 & 23 & 38 & 62 \\
\hline Pencemaran (udara, bau) & 52 & 48 & 95 & 5 & 77 & 23 & 35 & 65 \\
\hline $\begin{array}{l}\text { Keselesaan terma (suhu, } \\
\text { edaran udara) }\end{array}$ & 16 & 84 & 96 & 4 & 76 & 24 & 36 & 64 \\
\hline Ancaman kesihatan & 31 & 69 & 74 & 26 & 2 & 98 & 8 & 92 \\
\hline Tahap privasi & 17 & 83 & 10 & 90 & 28 & 72 & 0 & 100 \\
\hline Tahap keselamatan & 49 & 51 & 93 & 7 & 50 & 50 & 21 & 79 \\
\hline Kemudahan tempat letak kereta & 53 & 47 & 82 & 18 & 82 & 18 & 83 & 17 \\
\hline Lokasi perumahan & 14 & 86 & 12 & 88 & 4 & 96 & 0 & 100 \\
\hline Hubungan kejiranan & 9 & 91 & 18 & 82 & 21 & 79 & 7 & 93 \\
\hline
\end{tabular}

Nota: Nombor yang dihitamkan bermaksud respons yang diterima adalah melebihi 50 peratus 
Jadual 9. Masalah yang dihadapi oleh responden mengikut lokasi kajian

\begin{tabular}{|c|c|c|c|c|}
\hline Item & $\begin{array}{l}\text { Bukit Gedung } \\
\text { (Bayan Baru) }\end{array}$ & $\begin{array}{c}\text { Tun Sardon } \\
\text { (Gelugor) }\end{array}$ & $\begin{array}{l}\text { Flat Jalan Kedah } \\
\text { (George Town) }\end{array}$ & $\begin{array}{c}\text { Flat Bukit Jambul } \\
\text { (Bukit Jambul) }\end{array}$ \\
\hline $\begin{array}{l}\text { Jenis } \\
\text { perumahan }\end{array}$ & $\begin{array}{l}\text { Rumah kluster dan } \\
\text { rumah flat tanpa lif } \\
\text { (5 tingkat) }\end{array}$ & $\begin{array}{l}\text { Rumah flat/pangsa } \\
\text { tanpa lif ( } 5 \text { tingkat) }\end{array}$ & $\begin{array}{l}\text { Rumah flat/pangsa } \\
\text { (high rise) }\end{array}$ & $\begin{array}{l}\text { Rumah flat/pangsa } \\
\text { (high rise) }\end{array}$ \\
\hline Jumlah & 289 unit & 1,244 unit & 320 unit & 408 unit \\
\hline Pemaju & $\begin{array}{l}\text { Perbadanan } \\
\text { Pembangunan Pulau } \\
\text { Pinang }\end{array}$ & $\begin{array}{l}\text { Kerajaan Negeri } \\
\text { Pulau Pinang }\end{array}$ & $\begin{array}{l}\text { Perbadanan } \\
\text { Pembangunan Pulau } \\
\text { Pinang }\end{array}$ & Asas Dunia \\
\hline Lokasi & Bukit Gedung & Gelugor & George Town & Bukit Jambul \\
\hline $\begin{array}{l}\text { Masalah } \\
\text { dihadapi }\end{array}$ & $\begin{array}{l}\text { - Sempit/tidak luas } \\
\text { - Tiada pintu } \\
\text { belakang untuk } \\
\text { keluar-masuk } \\
\text { - Masalah } \\
\text { kebersihan } \\
\text { - Masalah parkir } \\
\text { - Jalan sempit dan } \\
\text { sesak } \\
\text { - Siling rumah } \\
\text { daripada papan } \\
\text { - Bunyi bising } \\
\text { (berhampiran } \\
\text { lapangan terbang) } \\
\text { - Kebanjiran warga } \\
\text { asing } \\
\text { - Suhu panas dalam } \\
\text { rumah } \\
\text { - Kecurian } \\
\text { - Masalah sampah } \\
\text { tidak dikutip } \\
\text { - Haiwan peliharaan } \\
\text { (bau busuk) } \\
\text { - Longkang tidak } \\
\text { bersih dan } \\
\text { tersumbat }\end{array}$ & $\begin{array}{l}\text { - Pembuangan } \\
\text { - } \text { Bampah } \\
\text { - Longkang } \\
\text { tersumbat } \\
\text { - Kecurian } \\
\text { - Masalah jiran } \\
\text { - Masalah parkir } \\
\text { - Semak samun di } \\
\text { belakang blok } \\
\text { - Penagih dadah } \\
\text { - Warga asing } \\
\text { - Letak barang } \\
\text { buangan sepanjang } \\
\text { tangga } \\
\text { - Tangga tidak } \\
\text { bersih } \\
\text { - Kebocoran } \\
\text { bumbung } \\
\text { - Halaman rumah } \\
\text { - yang sempit } \\
\text { Bumbung penuh } \\
\text { dengan sampah } \\
\text { - Jalan sempit } \\
\text { - Masalah kejiranan } \\
\text { Haiwan } \\
\text { peliharaaan }\end{array}$ & $\begin{array}{l}\text { - Lif rosak } \\
\text { - Air tidak bersih } \\
\text { - Paip bocor } \\
\text { - Kebocoran } \\
\text { bumbung (kualiti } \\
\text { bahan binaan) } \\
\text { - Masalah } \\
\text { kebersihan } \\
\text { terutamanya } \\
\text { sampah } \\
\text { Tingkah laku } \\
\text { penghuni } \\
\text { yang tidak } \\
\text { bertanggungjawab } \\
\text { seperti membuang } \\
\text { sampah dari } \\
\text { tingkat atas, } \\
\text { meletak barangan } \\
\text { buangan di koridor } \\
\text { dan tangga } \\
\text { Masalah warga } \\
\text { asing } \\
\text { Ruang parkir tidak } \\
\text { mencukupi }\end{array}$ & $\begin{array}{l}\text { - } \text { Masalah kecurian } \\
\text { (conteng dinding } \\
\text { dan lif, calar kereta, } \\
\text { pecah cermin) } \\
\text { - Kerosakan lif (satu } \\
\text { lif sahaja beroperasi) } \\
\text { - Masalah parkir } \\
\text { - Kaedah pembuangan } \\
\text { sampah tidak disukai } \\
\text { kerana terletak di } \\
\text { hujung bangunan } \\
\text { dan berdekatan } \\
\text { dengan tangga } \\
\text { - Tempat buang } \\
\text { sampah sentiasa } \\
\text { tersumbat dan } \\
\text { berbau busuk } \\
\text { - Pintu tempat } \\
\text { pembuangan } \\
\text { sampah rosak } \\
\text { - Longkang tidak } \\
\text { bersih } \\
\text { - Masalah lalat dan } \\
\text { lipas } \\
\text { - Koridor kotor } \\
\text { Kebisingan jalan } \\
\text { raya } \\
\text { Pihak pengurusan } \\
\text { tidak cekap dan } \\
\text { bertanggungjawab } \\
\text { Air tidak bersih }\end{array}$ \\
\hline
\end{tabular}

Walaupun hasil kajian menunjukkan dengan jelas faktor-faktor yang boleh mencetuskan tekanan perumahan di lokasi kajian, namun saiz sampel yang terhad dan pilihan lokasi kajian secara rawak telah menyebabkan wujudnya beberapa batasan dalam mengenal pasti secara statistik faktor-faktor yang menyumbang kepada tekanan perumahan. Hal ini juga disebabkan oleh hasil kajian yang melibatkan 
pengukuran pandangan atau penilaian subjektif individu yang berbeza. Walaupun hasil kajian dibincangkan secara deskriptif, ia telah berjaya mengenal pasti faktorfaktor yang menyumbang kepada tekanan perumahan di lokasi kajian dan dapat dijadikan petunjuk terhadap perasaan yang dialami oleh penghuni perumahan kos rendah dan sederhana rendah dalam bandar. Penyelidikan pada masa hadapan boleh memasukkan lebih banyak faktor yang berpotensi mempengaruhi tekanan perumahan agar dapat membantu pembuat dasar bagi memahami saling hubung antara perumahan dengan kesejahteraan hidup, khususnya kesan psikologi yang kurang diselidiki. Kajian berkaitan tekanan perumahan penting untuk dilakukan bagi meningkatkan pemahaman terhadap impak perumahan dan persekitaran kawasan perumahan kepada kehidupan penduduk. Hal ini adalah kerana tekanan perumahan boleh memberi kesan negatif terhadap kesihatan mental penduduk seperti kerisauan, kemurungan, paranoid, insomnia dan kegagalan hubungan sosial (Li dan Liu 2018). Perkara ini juga boleh memberi persepsi negatif terhadap kawasan perumahan tertentu seperti persekitaran yang tidak selamat, bising dan kotor.

\section{Kesimpulan}

Walaupun tekanan perumahan sering dikaitkan dengan bebanan atau tekanan daripada segi ekonomi, khususnya keupayaan penghuni untuk menanggung kos perumahan, namun didapati faktor bukan ekonomi juga boleh membawa kepada tekanan perumahan. Banyak kajian mendapati bahawa penduduk berpendapatan rendah dan sederhana rendah paling terkesan akibat kenaikan dalam kos perumahan dan kurangnya penawaran perumahan kos rendah dan sederhana rendah, terutama di kawasan bandar. Kajian yang telah dijalankan di beberapa kawasan perumahan kos rendah dan sederhana rendah dalam bandar di Pulau Pinang mendapati bahawa kualiti persekitaran perumahan ternyata lebih banyak memberi tekanan berbanding faktor ekonomi. Kesesakan penduduk, kekurangan ruang parkir, masalah kebersihan dan pencemaran, tahap keselesaan terma dan keselamatan telah menjadi faktor bukan ekonomi yang menyumbang kepada tekanan perumahan dalam kalangan responden kajian. Faktor ekonomi yang memberi tekanan perumahan ialah kos pengangkutan (kenaikan harga bahan api). Walaupun perumahan kos rendah dan sederhana rendah dapat memenuhi keperluan tempat tinggal bagi golongan berpendapatan rendah dan sederhana, namun terdapat beberapa kekurangan yang memberi tekanan kepada penghuninya, terutama daripada segi kesejahteraan dan kualiti hidup. Oleh itu, dalam mendapatkan pemahaman yang lebih baik terhadap faktor-faktor yang boleh menyumbang kepada tekanan perumahan, konseptualisasi perumahan seharusnya diperluaskan meliputi kedua-dua aspek perumahan, iaitu rumah/unit kediaman dan persekitaran kejiranan kawasan perumahan. Strategi perancangan dan pembangunan perumahan, khususnya bagi perumahan kos rendah 
dan sederhana rendah dalam bandar, perlu juga memberi perhatian terhadap aspek persekitaran kejiranan supaya perumahan yang disediakan dapat menyumbang kepada kualiti hidup yang lebih baik. Walau bagaimanapun, hasil kajian yang dibincangkan dalam makalah ini mempunyai batasan daripada segi data yang lebih terperinci dalam mengenal pasti secara khusus faktor-faktor yang boleh mencetuskan tekanan perumahan dalam kalangan responden. Pemerolehan data secara entnografi diperlukan supaya penilaian yang baik dan terperinci dapat dibuat dalam menilai pandangan dan pengalaman subjektif penduduk terhadap faktorfaktor yang menyumbang kepada tekanan perumahan. Namun, hasil kajian ini menunjukkan bahawa konseptualisasi tekanan perumahan yang menjurus kepada faktor ekonomi adalah tidak mencukupi dan seharusnya diperluaskan meliputi faktor bukan ekonomi kerana faktor ini didapati lebih banyak menyumbang kepada tekanan perumahan berbanding faktor ekonomi.

\section{Penghargaan}

Makalah ini merupakan sebahagian daripada hasil penyelidikan Geran Universiti Penyelidikan, Universiti Sains Malaysia (RU-USM) (1001/PHUMANITI/816266). Penulis merakamkan terima kasih kepada USM atas peruntukan kewangan dan bantuan dalam menjayakan kajian ini.

\section{Rujukan}

Afon, A. 2006. The use of residents' satisfaction index in selective rehabilitation of urban core residential areas in developing countries. International Review for Environmental Strategies 6(1): 137-152.

Ahmad Ezanee Hashim, Siti Aida Samikon, Nasyairi Mat Nasir and Normazwin Ismail. 2012. Assessing factors influencing performance of Malaysian low-cost public housing in sustainable environment. Procedia - Social and Behavioral Sciences 50(2012): 920-927. https://doi.org/10.1016/j.sbspro.2012.08.093

Atchley, R.C. 2004. Social forces and aging: An introduction to social gerontology (10th ed.). Belmont, CA: Thomson Learning.

Abdul-Aziz, W. 2007. Low-cost housing policy in Malaysia: The challenge of delivery. $\mathrm{PhD}$ dissertation, University of Dundee.

Abdul Ghani Salleh. 2008. Neighbourhood factors in private low-cost housing in Malaysia. Habitat International 32(4): 485-493. https://doi.org/10.1016/j. habitatint.2008.01.002

Baqutayan, S.M.S. 2014. The affordable housing stress among middle-income group. Journal of Humanities and Social Science 19(7): 82-90.

2016. Is affordable housing an issue? A case study of housing stress among middle-income group in Malaysia. International and Multidisciplinary Journal of Social Sciences 5(1): 26-50. https://doi.org/10.17583/rimcis.2016.1871 
Baqutayan, S.M.S., Ariffin, A.S. and Raji, F. 2015. Affordable housing policy: Issues and challenges among middle-income groups. International Journal of Social Science and Humanity 6(6): 443-436. https://doi.org/10.7763/ijssh.2016.v6.686

Berg, A.E., Hartig, T. and Staats, H. 2007. Preference for nature in urbanized societies: Stress, restoration and the pursuit of sustainability. Journal of Social Issues 63(1): 79-96. https://doi.org/10.1111/j.1540-4560.2007.00497.x

Bonnefoy, X. 2007. Inadequate housing and health: An overview. International Journal of Environment and Pollution 30(3/4): 411-429.

Cantarero, R. and Potter, J. 2012. Stress and the contextual proximity of residential factors. Procedia - Social and Behavioral Sciences 36(2012): 137-146. https://doi. org/10.1016/j.sbspro.2012.03.016

Disney, J. 2006. Over our heads: Housing costs and Australian families. Australian Quarterly 78(2): 4-11. https://doi.org/10.2307/20638385

Djebarni, R. and Al-Abed, A. 2000. Satisfaction level with neighbourhoods in low-income public housing in Yemen. Property Management 18(4): 230-242. https://doi. org/10.1108/02637470010348744

Dunn, J.R. 2002. Housing and inequalities in health: A study of socioeconomic dimensions of housing and self-reported health from a survey of Vancouver residents. Journal of Epidemiology and Community Health 56(9): 671-681. https://doi.org/10.1136/ jech.56.9.671

Edwards, B. and Turrent, D. 2000. Sustainable housing: Principles and practice. London: E \& FN Spon.

Evans, G.W., Wells N.M., Chan H.Y. and Saltzman H. 2000. Housing quality and mental health. Journal of Consulting and Clinical Psychology 68(13): 526-530. https://doi.org/10.1037//0022-006x.68.3.526

Fang, Y. 2005. Residential satisfaction conceptual framework revisited: A study on redevelopment neighbourhoods in inner city Beijing. USA: University of Colorado at Denver.

Gabriel. M., Jacobs, K., Arthurson, K., Burke, T. and Yates, J. 2005. Conceptualising and measuring the housing affordability problem. In National Research Venture 3: Housing affordability for lower income (Australians Research Paper No. 1). Melbourne: Australian Housing and Urban Research Institute.

Ghani Salleh and Lee Lik Meng. 1997. Low-cost housing in Malaysia. Kuala Lumpur: Utusan Publication \& Distributors Sdn. Bhd.

Grimes, A., Kerr, S. and Aitken, A. 2003. Housing and economic adjustment (Motu Economic and Public Policy Research Trust, Motu Working Paper \#03-09). Wellington: Motu Economic \& Public Policy Research. https://doi.org/10.29310/ wp.2003.09

Husna Sulaiman and Nurizan Yahaya. 1987. Housing provision and satisfaction of low income households in Kuala Lumpur. Habitat International 11(4): 27-38. https://doi.org/10.1016/0197-3975(87)90006-3

Hulse, K., Burke, T., Ralston, L. and Stone, W. 2010. The benefits and risks of home ownership for low-moderate income households (AHURI Final Report No: 154). Melbourne: Australian Housing and Urban Research Institute. 
ISIS (Institute of Strategic and International Studies, Malaysia). 2013. ISIS roundtable: Providing public and affordable housing for Malaysia. http://www.isis.org.my/files/ IF_2013/IF3 2013.pdf (accessed 24 February 2016).

Jabatan Perangkaan Malaysia. 2014. Laporan penyiasatan pendapatan isi rumah dan kemudahan asas (HIES). Putrajaya: Jabatan Perangkaan Malaysia.

2015. Buletin Perangkaan Sosial Malaysia 2015: Perumahan. Putrajaya: Jabatan Perangkaan Malaysia.

Jabatan Perumahan Negara. 2016. Laporan Perangkaan Perumahan 2016, Kementerian Kesejahteraan Bandar, Perumahan dan Kerajaan Tempatan. http://ehome.kpkt.gov. my/index.php/pages/view/36 (accessed 29 March 2019).

Kajimo, S.K. and Evans, K. 2006. The role of banks in the provision of low-income housing finance in South Africa: Can they play a different role? International Journal of Strategic Property Management 10(1): 23-38. https://doi.org/10.3846/ $1648715 x .2006 .9637542$

Karantonis, A. 2009. No pain, no gain: The issue of housing stress. Australia and New Zealand Property Journal 2(2): 88-97.

Kellekci, O.L. and Berkoz, L. 2006. Mass housing: User satisfaction in housing and its environment in Istanbul, Turkey. European Journal of Housing Policy 6(1): 77-99. https://doi.org/10.1080/14616710600587654

Khazanah Research Institute. 2015. Making housing affordable. Kuala Lumpur: Khazanah Research Institute.

KPKT (Kementerian Kesejahteraan Bandar, Perumahan dan Kerajaan Tempatan). 2015. Perangkaan KPKT 2015. Putrajaya: Kementerian Kesejahteraan Bandar, Perumahan dan Kerajaan Tempatan. http://www.kpkt.gov.my/resources/index/ user_1/GALERI/PDF_PENERBITAN/PERANGKAAN\%20TERPILIH/Buku_ Perangkaan_KPKT_2015_updated.pdf (accessed 18 July 2016).

Lawson J. and Miligan V. 2008. International trends in housing and policy respons (AHURI Final Report No. 16). Melbourne: Australia Housing and Urban Research Institute.

Lee, E. and Park, N. 2010. Housing satisfaction and quality of life among temporary residents in the United States. Housing and Society 37(1): 43-67. https://doi.org/10 $.1080 / 08882746.2010 .11430580$

Leishman, C. and Rowley, S. 2012. Affordable housing. In The SAGE handbook of housing studies, eds. D.F. Clapham, W.A.V. Clarke and K. Gibb, 379-396. London: Sage. https://doi.org/10.4135/9781446247570.n20

Li, J. and Liu, Z. 2018. Housing stress and mental health of migrant populations in urban China. Cities 81(November): 172-179. https://doi.org/10.1016/j.cities.2018.04.006

Malaysia. 2015. Rancangan Malaysia Kesebelas (2016-2020). Kuala Lumpur: Percetakan Nasional Malaysia Berhad.

Maliene, V. and Malys, N. 2009. High quality housing: A key issue in delivering sustainable communities. Building and Environment 44(2): 426-430. https://doi.org/10.1016/j. buildenv.2008.04.004

McCray, J.W. and Day, S.S. 1977. Housing values, aspiration and satisfactions as indicators of housing needs. Family and Consumer Sciences Research Journal 5(4): 244-254. https://doi.org/10.1177/1077727x7700500404 
Mohd Razali Agus. 1984. Perumahan awam di Malaysia: Dasar dan amalan. Kuala Lumpur: Utusan Publications Sdn. Bhd.

2001. Peranan kerajaan dalam pengagihan perumahan awam di Malaysia: Satu kajian perbandingan. Kuala Lumpur: Utusan Publications Sdn. Bhd.

Mohit, M.A., Ibrahim, M. and Rashid, Y.R. 2010. Assessment of residential satisfaction in newly designed public low-cost housing in Kuala Lumpur, Malaysia. Habitat International 34(1): 18-27. https://doi.org/10.1016/j.habitatint.2009.04.002

Morshidi Sirat, Abdul Fatah Che Hamat, Abdul Rashid Abdul Aziz, Alip Rahim, Halim Salleh and Usman Hj. Yaakob. 1999. Low-cost housing in urban industrial centres of Malaysia: Issues and challenges. Pulau Pinang: Penerbit Universiti Sains Malaysia.

Mueller, E.J. and Tighe, R. 2007. Making the case for affordable housing: Connecting housing with health and education outcomes. Journal of Planning Literature 24(4): 371-385.

Mulok, D. and Kogid, M. 2008. Low-cost housing in Sabah, Malaysia: A regression analysis. Asian Social Science 4(12): 27-33. https://doi.org/10.5539/ass.v4n12p27

Nepal, B., Tanton, R. and Harding, A. 2010. Measuring housing stress: How much do definition matter? Urban Policy and Research 28(2): 211-224. https://doi. org/10.1080/08111141003797454

Nepal, B., Tanton, R., Harding, A. and McNamara, J. 2008. Measuring housing stress at small area levels: How much do definition matter? Paper presented at the 3rd Australian Housing Researchers Conference, Melbourne, 18-20 June 2008.

Nor Malina Malek and Azrina Husin. 2012. Pemilikan rumah dalam kalangan masyarakat bandar berpendapatan sederhana dan rendah di Malaysia. SOSIOHUMANIKA 5(2): 269-284.

Nor Aini Haji Idris and Chamhuri Siwar. 2003. Kemiskinan bandar dan sektor tidak formal di Malaysia. Bangi: Universiti Kebangsaan Malaysia.

Nor Baizura Jamaludin, Yusfida Ayu Abdullah and Hazlina Hamdan. 2016. Encapsulating the delivery of affordable housing: An overview of Malaysian practice. In 4th International Building Control Conference (IBCC 2016), MATEC Web of Conference, Volume 66, eds. Syahrul Nizam Kamaruzzaman, Azlan Shah Ali, Nur Farhana Azmi and Shirley Chua Jin Lin, 335-342. https:/www.matec-conferences. org/articles/matecconf/pdf/2016/29/ matecconf_ibcc2016_00047.pdf (accessed 26 February 2016). https://doi.org/10.1051/matecconf/20166600047

Nurizan Yahya and Ahmad Hariza Hashim. 2001. Perumahan dan kediaman. Serdang: Universiti Putra Malaysia.

Ogu, V.I. 2002. Urban residential satisfaction and the planning implications in a developing world context: The example of Benin City, Nigeria. International Planning Studies 7(1): 37-53. https://doi.org/10.1080/13563470220112599

Puddiffot, J.E. 1994. Community identity and sense of belonging in a Northeastern Englishtown. The Journal of Social Psychology 134(5): 601-608.

Quigley, J.M. and Raphael, S. 2004. Is housing unaffordable? Why isn't it more affordable? The Journal of Economic Perspectives 18(1): 191-214. https://doi. org/10.1257/089533004773563494

REHDA (Real Estate and Housing Developers' Association, Malaysia). 2008. The way forward for the construction industry. Kuala Lumpur: REHDA. 
Rowley, S. and Ong, R. 2012. Housing affordability, housing stress and household wellbeing in Australia (AHURI Final Report No. 192). Melbourne: Australian Housing and Urban Research Institute. http://www.ahuri.edu.au/_data/assets/pdf_ file/0010/2215/AHURI_Final_Report_No192_Housing_affordability,_housing_ stress_and_household_wellbeing_in_Australia.pdf (accessed 24 February 2016).

Sandel, M. and Wright, R.J. 2006. When home is where the stress is: Expanding the dimensions of housing that influence asthma morbidity. Archives of Disease in Childhood 91(11): 942-948. https://doi.org/10.1136/adc.2006.098376

Smith, S.J., Searle, B.A. and Cook, N. 2009. Rethinking the risks of home ownership. Journal of Social Policy 38(1): 83-102.

Stone, M., Burke, T. and Ralston, L. 2011. The residual income approach to housing affordability: The theory and the practice (Positioning Paper No. 139). Melbourne: Australian Housing and Urban Research Institute.

Stone, M.E. 2006. What is housing affordability? The case for residual income approach. Housing Policy Debate 17(1): 151-184. https://doi.org/10.1080/10511482.2006.95 21564

Tan, T.H. 2008. Determinants of home ownership in Malaysia. Habitat International 32(3): 318-335.

2011. Housing satisfaction in medium and high cost housing: The case of Greater Kuala Lumpur, Malaysia. Habitat International 36(1): 108-116. https://doi. org/10.1016/j.habitatint.2011.06.003

Tosics, I. 2004. European urban development: Sustainability and the role of housing. Journal of Housing and the Built Environment 19(1): 67-90. https://doi.org/10.1023/ b:joho.0000017707.53782.90

Vidyattama, Y., Tanton, R. and Nepal, B. 2011. Housing stress or transport stress? Issues in Australian housing affordability (NATSEM Working Paper 11/06). Australia: NATSEM, University of Canberra. https://natsem.canberra.edu.au/ storage/Housing\%20Stress\%20or\%20Transport\%20Stress\%20Issues\%20in\%20 Australian\%20Housing\%20Affordability_final.pdf (accessed 26 May 2015).

Vu, Q.N. 2007. The effect of rent increases on housing stress in Australia. Australia: University of Canberra.

Yates, J. and Milligan, V. 2007. Housing affordability: A 21st century problem. In National Research Venture 3: Housing Affordability for lower income Australians (AHURI Final Report No. 105). Melbourne: Australian Housing and Urban Research Institute. 